\title{
УКРАЈИНСКИ ПУТЕВИ СРПСКЕ КЬИЖЕВНОСТИ: ОСОБЕНОСТИ (ПОСТ)МОДЕРНЕ РЕЦЕПЦИЈЕ
}

\begin{abstract}
У овом раду бавимо се питањем рецепције српске књижевности у савременој Украјини (1998-2020). Кренувши од примера академске рецепције, разматрамо главне векторе преводилачког и књижевно-историјског интересовања за дела српских писаца током ове две деценије, утицај српске књижевности на стваралаштво савремених украјинских писаца, реакције украјинске књижевне критике на објављене у Украјини преводе. Посвећује се пажња особеностима украјинске рецепције које диктирају како културолошки разлози, тако и политички догађаји у ове две земље. Посебан акценат ставља се на постмодерне облике рецепције, пре свега везане за перформативност, интересовање за личност писца, као и на сведочанства рецепције дела српских књижевника на друштвеним мрежама, блоговима и другим постмодерним медијима.

Кључне речи: српска књижевност, рецепција, постмодерно доба, српско-украјинске књижевне везе.
\end{abstract}

Питање рецепције српске књижевности у Украјини 21. века може се сматрати веома занимљивим како за научнике који се баве питањима међусловенских културних веза, тако и за проучаваоце постмодерне рецепције књижевних дела у другим културама. Богатство материјала, разноврсност рецепцијских стратегија и облика дозвољава да издвојимо нове тенденције у процесима рецепције које су настале у последњих двадесетак година. Осим навођења важних чињеница рецепције српске књижевности у савременој Украјини покушаћемо да одредимо главне смерове рецепцијског деловања, нове рецепцијске појаве, као и оне које су карактеристичне управо за украјинску рецепцију српских књижевних дела.

Питањима српско-украјинских књижевних веза (у том броју савременим) активно се бави српски слависта Дејан Ајдачић. У својим радовима често је спомињао делатност украјинских преводилаца и истраживача српске књижевности (Ајдачић 2005; Ајдачић 2007; Ајдачић 2010; Ајдачић 2015). За-

*alla.tatarenko@Inu.edu.ua 
гребачки украјиниста Јевгениј Пашченко (Пашченко 2017) поклања пажњу одређеним моментима рецепције савремене књижевности Срба у Украјини у контексту представљања рецепције актуелне хрватске књижевности и развоја хрватске и српске украјинистике. Питањима савремене српске прозе у Украјини бавила се у вези са стваралаштвом Звонка Карановића и Срђана Ваљаревића украјинска слависткиња Олга Антонова (Антонова 2018). Рецепција дела Иве Андрића у Украјини била је један од аспеката докторских истраживања Наталије Билик (види нпр.: Билик 2003). Посебни радови посвећени су особеностима украјинске рецепције стваралаштва Данила Киша (Антонова 2017, Татаренко 2001), Милорада Павића (Татаренко 2003; Татаренко 2006), променама до којих је дошло у представљању српске књижевности на крају 20. века (Татаренко 2002), стратегијама рецепције дела српских аутора у Украјини 21. века (Татаренко 2018). О србистичким интересовањима професора универзитета „Тарас Шевченко” у Кијеву пише Лесја Стеблина Рудјакова (Стеблина Рудјакова 2009), а о преводилачким активностима србиста катедре за славистику Универзитета „Иван Франко” у Лавову можемо да прочитамо у чланку „Мостови међукултурне сарадње” (Лобур, Моторний, Татаренко 2014). Преводи српске књижевности на украјински језик, као и радови украјинских историчара српске књижевности, представљени су у библиографском издању Српски фолклор и књижевност у украјинским преводима и истраживањима. 1837-2004. (Ајдачић и др. 2005). Пошто нема издања које би приказало рецепцију српске књижевности у тим сегментима након 2004, посветићемо пажњу том питању у овом раду.

Академска рецепција српске књижевности у савременој Украјини има дугачку историју и, верујемо, добре перспективе. Украјински истраживачи у 21. веку настављају традицију проучавања класика: као пример навешћемо докторате о стваралаштву Иве Андрића представница кијевске школе славистике Наталије Билик („Иво Андрић и Украјина: контакти, рецепција, типологија”) и Олене Деркач („Женска персоносфера Иве Андрића: концептуални принципи и семантичке конфигурације"). Њихов ментор Павел Рудјаков посвећивао је посебну пажњу стваралаштву нобеловца. У фокусу интересовања украјинских слависта нашле су се и теме које раније нису биле предмет проучавања у Украјини - на пример, стварносна проза коју анализира лавовска слависткиња Марија Василишин. Њена колегиница Христина Стељмах испољила је интересовање за „женско писмо” у српској књижевности, одбранила дисертацију о стваралаштву Јасмине Тешановић. Скоро истовремено представнице кијевске и лавовске славистике бавиле су се романескним стваралаштвом М. Павића: Јулија Билоног (Драгојловић) одабрала је за проучавање парадигму „аутор-читалац”, док је Зорјана Хук разматрала постмодернистичке особине романа српског класика. Као што видимо, у 21. веку украјински слависти почели су да се окрећу стваралаштву класика послератне књижевности: Марина Гогуља посветила је дисертацију прозном стваралаштву Данила Киша, док је Ирина Моцна написала низ радова о делу Борислава Пекића. Дисертацију о југословенском „ратном” роману у књижевности 70-80-их година 20. века одбранила је Свитлана Пастух, а прозни концепти у српској књижевности друге половине 20. века (Д. Киш, 
С. Селенић, Д. Албахари) нашли су се у средишту интересовања Лилије Токареве. Пажњу млађих истраживача привлачи и најновија, постпостмодернистичка књижевност, као и теме везане за најновију историју Србије: Олга Антонова одбранила је докторат о балканској кризи у српској књижевности, ослањајући се у својој анализи на дела Звонка Карановића, Угљеше Шајтинца, као и на Дневник једне српске домаћице Мирјане Бобић Мојсиловић. Ово сведочи о проширењу поља истраживања украјинских слависта, као и о изласку из оквира тзв. високе књижевности.

Резултате својих истраживања представиле су у облику монографија Олена Деркач (Деркач 2013) и Марина Гогуља (Гогуља 2019). Хабилитационе монографије објавиле су Наталија Билик, у центру чијег компаративистичког рада се налази стваралаштво Милете Продановића (Билик 2019), и Ала Татаренко, чија је студија о поетици форме у прози српског постмодернизма објављена (у нешто прерађеном облику) и на српском језику (Татаренко 2010). Као прехабилитациону можемо третирати монографију Олене Дзјубе Погребњак о Првом светском рату у књижевностима Јужних Словена (Дзјуба Погребњак 2014).

Проучавањем српске књижевности баве се и најмлађи украјински слависти - студенти универзитета у Кијеву и Лавову. Године 2009. одржала се прва студентска научна славистичка конференција он-лајн. У њој су узели учешће како студенти србистике, тако и њихове колеге са других филолошких одсека који су се прикључили проучавању србистичких тема. То је постало могуће захваљујући постојању превода, као и захваљујући залагању професора тих универзитета. У овом контексту посебну захвалност дугујемо Дејану Ајдачићу, који је на више начина допринео јачању украјинске србистике и проширењу поља рецепције. Настављајући тему студентских скупова споменула бих другу конференцију младих србиста чији је spiritus movens био проф. Ајдачић и чији су материјали били објављени као посебно издање.

Међу значајним пројектима које је покренуо овај научник, споменућемо оснивање и објављивање украјинско-српског алманаха УКРАС, који је дао значајан допринос популаризацији знања о српској историји, култури, књижевности. У пројекте који су имали за циљ ширу рецепцију српске књижевности у Украјини, спада и хрестоматија Српска књижевност 20. века, која садржи преводе дела, значајних за развој књижевности Срба у прошлом столећу (Ајдачић, Татаренко 2016). Ваља споменути још један врло значајан пројекат који је реализовао Д. Ајдачић, а то је библиотека Растко-Кијев-Лавов као део „Пројекта Растко” - библиотеке српске културе на интернету. Овде можемо наћи изврсну збирку превода дела украјинских књижевника на српски и vice versa, читаве славистичке монографије и посебне чланке. Ова електронска библиотека већ двадесет година служи као поуздано место знања за генерације слависта и радозналих читалаца. Овакви важни подухвати сигнализирају о изласку академске рецепције из ужих оквира научних издања, као и о настојању слависта да упознају са делима српске књижевности што шире кругове читалаца, у том броју оне који не владају српским језиком, али су заинтересовани за стваралаштво српских писаца. 
Крајем 20. и почетком 21. века долази до промена у издаваштву које постаје независно, али и препуштено законима тржишта. Ситуација кад држава финансијски није помагала преводилачке пројекте, али их зато није ни контролисала, отворила је нове могућности. Слависти (прво професори универзитета, а онда и њихови студенти) постају иницијатори превођења дела српске књижевности на украјински. Први издавач који је испољио знатно интересовање за српску књижевност 20. века, била је ИК Класика (Лавов). У периоду од 1998. до 2002. овде су изашли преводи романа Милорада Павића Хазарски речник, Последюа љубав у Цариграду, Звездани плашт; приповедне књиге Данила Киша Енщиклопедија мртвих и Гробница за Бориса Давидовича; роман Моме Капора Фолиранти. Издавач је приредио представљање ове колекције на сцени Дворца уметности у Лавову. То је била једна од првих изузетно посећених промоција савремене српске књижевности, у којој су учествовали преводиоци. Књижевне вечери и промоције књига српских аутора, као и учешће писаца на књижевним фестивалима, постали су веома важан фактор рецепције културе Срба у Украјини.

Резултати ове појачане дозе српске књижевности били су богати и разноврсни. Енициклопедија мртвих Д. Киша надахнула је украјинску теоретичарку књижевности Ирину Старовојт, која је у то време радила на телевизији, на стварање филма посвећеног овом класику. У књигама млађих украјинских писаца (нпр., код Ирене Карпе) почели су да се појављују интертекстуални трагови дела српске књижевности. Познати украјински песник Игор Римарук прочитао је по наговору слависта, песника и преводиоца Ивана Лучука Павићев Хазарски речник и укључио фрагмент из те књиге као мото у своју поему Девица Увреда (и добио за то дело највећу украјинску награду за књижевност). Хазарски речник имао је иначе посебан утицај на читаоце у Украјини. Вајарка Тетјана Кручинина направила је од керамике девет фигура принцезе Атех, од којих свака носи цитат из Павићевог романа, а филм о тој изложби освојио је награду на фестивалу у Кијеву (детаљније о томе: Татаренко 2014).

Српска књижевност постала је занимљива за украјинске читаоце и ван славистичких кругова. Нажалост, бомбардовање Југославије 1999. преусмерило је (на неко време) интересовање читалаца на историјске и политичке околности. Тематски број украјинског независног културолошког часописа Ju (www.ji.lviv.ua) „Југославија, Косово, Европа” (2000) упознао је украјинску публику са драматичним манифестацијама косовске кризе, али већину простора уредници су посветили представљању српске књижевности. Овде су били објављени есеји и приповетке Данила Киша и Милорада Павића, фрагменти дневничких записа Милисава Савића, вођених за време бомбардовања, као многи други текстови, све до песме И. Лучука, која представља успомену на сусрет са Павићем, и сећања преводитељице Хазарског речника Олге Рос о томе како је она радила на том делу.

Почетком 21. века проширује се круг часописа који објављују преводе српске књижевности и књижевно-критичке текстове о њој. Осим украјинског часописа за светску књижевност Всесвит, то су часописи Курјер Крив- 
басу, Ju, Форма(р)m и други. Бројне текстове о српској књижевности објавио је електронски часопис ЛитАкиент. Ова традиција траје и данас, у нешто промењеном облику у складу са променама у читалачком профилу наших савременика. О томе сведочи збирка текстова објављених у ЛитАкценту, коју је приредио Дејан Ајдачић. Два издања ових занимљивих сведочанстава рецепције српске књижевности у Украјини (у преводу на српски) показују промене у читалачкој рецепцији, али и њену ширину (Ајдачић 2015). Текстови слависта упућених у оригинале смењују се рецензијама критичара који су читали преводе, интервјуима са српским писцима који су постали препознатљиви и омиљени (С. Дамјанов, М. Продановић, С. Срдић).

Рецепција српске књижевности у овом столећу обележена је постмодернистичким особинама, у том броју литературоцентризмом и занимањем за фантастично. У прилог тој тези служи објављивање на украјинском Антологије српске постмодерне фантастике Саве Дамјанова (2004) и антологијског избора Неодољиви ерос приче, који је саставила ауторка ових редова (Нездоланний ерос оповідi, 2009). Излазак антологија представља корак у сусрет будућим књигама: читаоци (и издавачи) добијају могућност да се упознају са новим ауторима и њиховим делима. Такву улогу одиграла је и антологија савремене српске драме (Новітня сербська n'єса, 2006), коју је приредио Д. Ајдачић. У њој је била објављена драма Небојше Ромчевића „Кривица”, а 2013. избор из Ромчевићевих драма изашао је као посебно издање. Као посебно издање изашла је и драма Виде Огњеновић „Милева Ајнштајн”, а први превод њеног драмског дела „Је ли било кнежеве вечере” објављен је у споменутој антологији.

Улогу својеврсне визиткарте имао је и тематски број алманаха „Воз 76. Балкан експрес" (2007). Већина аутора заступљених у њему добила је касније у Украјини посебна издања својих дела, а међу њима су Михајло Пантић, Звонко Карановић, Милета Продановић.

Српска поезија у украјинским преводима представљена је изабраним песмама Звонка Карановића (2011), Гојка Божовића (2019), Алена Бешића (2020) (спомињемо само посебна издања, мада има немали број песама и песника, представљених у часописима). Најмање се преводи дечија књижевност, мада и ту има занимљивих издања, међу којима су збирка дечијих песама у преводу Оксане Сенатович (Маче у мепу) и низ превода изузетно духовитих издања Креативног центра (едиција „Без длаке на језику”).

Српска проза преводи се највише, и ту можемо да нађемо књиге за веома различите читалачке укусе. Објављена су многа значајна дела класика књижевности 20. века као и дела наших савременика. Навешћемо као пример Дневник о Чарнојевићу М. Црњанског, Кад су ияветале тикве Д. Михаиловића, Нови Јерусалим Борислава Пекића, Мансарду и Кюигу љубави и смрти (у коју су ушле три приповедне књиге) Д. Киша. Наслов Кишовог „трокњижја” представља идеју уредника украјинског издања. Књигу таквог наслова нећете наћи у оригиналу, као и књигу Горана Петровића Острво и друга виђења. Нови наслови симболизују нови живот дела у новом језику. 
Истраживачи српске књижевности постају преводиоци дела која проучавају, а самим тим и њихови популаризатори: то су, на пример, Марија Василишин, која је превела Михаиловићев роман, Наталија Билик - проучаватељка и преводитељица дела М. Продановића, Марина Гогуља, која је превела неколико приповедака из збирке Рани јади Д. Киша и др. Почињу да се активно баве превођењем познати украјински србисти: истраживачица фолклора Оксана Микитенко (превела је Ако је то љубав М. Пантића), лингвисте Вероника Јармак (преводитељица романа В. Огњеновић Прељубници) и Наталија Хороз (преводитељица романа В. Кецмановића Феликс). Међу преводиоцима српске књижевности највише има универзитетских професора (осим већ споменутих то су О. Дзјуба-Погребњак, 3. Хук, Х. Стељмах, О. Деркач, М. Климец, А. Татаренко), али и представника других филолошких сфера (Н. Чорпита, И. Лучук, О. Концевич и др).

Активизацију процеса рецепције српске књижевности запажамо у последњих десет година, кад дела српских писаца почињу да преводе млади, али већ популарни писци. Веома запажену улогу имају у тим процесима Андриј Љупка (превео је Комо С. Ваљаревића, Фаму о бициклистима С. Басаре, У потпалубљу В. Арсенијевића и др.) и Катерина Калитко (преводитељица романа М. Селимовића Дервиш и смрт, приповедне књиге М. Пантића Ходање по облачима, Продановићеве Аркадије, Шајтинчевих Сасвим скромних дарова и др). Популарност тих писаца као оригиналних стваралаца привлачи пажњу читалаца и ка њиховим преводима, ширећи коло оних који се занимају за српску књижевност.

У обогаћивању „српске библиотеке” украјинских читалаца играју улогу и студенти-србисти - како актуелни, тако и некадашњи. Студенти из Лавова су превели књигу по свом избору (Дванаест збирки и чајциница Зорана Живковића). Кијевски млади слависти превели су Ултрамарин М. Продановића (Људмила Недашкивска), Снежног човека Д. Албахарија (Олесја Кривонис). Некадашњи студенти славистике реализују снове савремених класика украјинске књижевности: на предлог Јурија Виничука Олена Концевич је превела приче Филипа Давида.

Популарност и даље уживају дела М. Павића (осим преведених за ИК Класика романа навешћу приповедну књигу Еротске приче). „Дамаскин” и „Стаклени пуж” ушли су у програм украјинских средњих школа, а на интернету може се наћи адаптирана за децу биографија Милорада Павића.

На веома добар пријем наишле су књиге Горана Петровића. Од посебних издања споменућу збирку приповедне прозе Острво и друга виђења (2007), романе Ситничарница Код срећне руке (2017) и Атлас описан небом (2019). Изузетно добро била је примљена постмодернистичка Ситничарница (ускоро излази друго издање превода), за коју се заинтересовала млађа генерација читалаца. Сведоче о том интересовању бројне рецензије књижевних критичара и обичних читалаца, мишљења видеоблогера која се могу наћи на Јутубу. Младе блогерке упоређују овај роман са Булгаковљевим романом Majстор и Маргарита (због тајанствене атмосфере) или чак са филмом $3 a$ творено острво (из истог разлога). Ово може да сведочи о томе како у улози 
паралеле не наступа више књижевност (или књижевност исте поетике), већ се у првом плану налази емотивни доживљај.

Пронашле су своје читаоце у Украјини и књиге постмодерних писаца Звонка Карановића и Срђана Срдића. Карановић је стекао обожаваоце у Украјини прво као песник и аутор романа Четири зида и град. У овим делима млађи Украјинци препознали су слични музички код, ритам рок генерације. На интернет форумима читаоци су изражавали жаљење што има тако мало превода, а неки су били спремни читати Карановића на српском. Осим бројних промоција и читања са учешћем Карановића, који је више пута био гост књижевних фестивала и сајмова у Лавову и Кијеву, овај писац био је јунак књижевне вечери „Савремена српска поезија” (Кијев, 2013), која се одржала без присуства аутора, али је зато звучала музика која прожима његово песништво.

Са почетком рата на Истоку Украјине украјински читаоци и издавачи почели су испољавати интересовање за ратну књижевност. Године 2015. изашао је превод романа С. Срдића Сатори, 2016. - Три слике победе 3. Карановића, а у романе о повратку из рата можемо сврстати и Дневник о Чарнојевићу (украјински превод објављен је 2015). Као сведочанство посебне пажње према теми рата у српској књижевности навешћемо текст књижевне критичарке Оксане Шчур (Шчур 2015), а о томе сведоче и питања која су постављали украјински новинари С. Срдићу и 3. Карановићу.

У особине постмодерне рецепције спада и пажња према визуелном елементу издања. Већина корица споменутих књига има своју причу. У одсуству илустрација које би приказале уметниково виђење јунака оне сведоче о доживљавању духа књиге. Оригинално графичко решење Срдићевог Cатоpuja - резултат „сродности по слушању” графичког уредника А. Сендзјука и српског писца: музика која звучи у роману одјекује у поетици визуелног уметника. Ауторка графичког решења корица Петровићевих романа М. Кинович ушла је са корицом Атласа у најужи избор светске награде за илустраторе. Визуелни уметници знају да прекодирају дух речи и дух музике у дух слике, и та синестезија такође представља једну од особина постмодерне епохе. Дакле, сведочанства рецепције српске књижевности нису сада само текстови, већ и слике.

Ослањајући се на ове и многе друге чињенице можемо устврдити да је српска књижевност у Украјини у 21. веку заузела значајно и видљиво место. На томе захваљујемо бројним преводиоцима, професорима, истраживачима, издавачима, књижевним критичарима, али и Министарству културе и информисања Републике Србије, које већ више од десет година подржава објављивање превода српске књижевности на стране језике. Захваљујемо МСЦ-у, који је постао за украјинске србисте (као и за србисте других земаља) најбоља школа знања и љубави према српском језику и књижевности. Зато, са дубоким и искреним поштовањем, посвећујем ово истраживање Међународном славистичком центру на Филолошком факултету Универзитета у Београду. 


\section{ЛИТЕРАТУРА}

Ајдачић и др. 2005: Д. Айдачич та ін. Сербські фольклор і література в украӥнських перекладах і дослідженнях. 1837-2004: Матеріали до бібліографії, Київ: НБУВ.

Ајдачић 2005: Д. Ајдачић, Украјински преводиоци српске књижевности, Београд: Славистика, 9, 372-380.

Ајдачић 2007: Д. Ајдачић, Украјинска србистика - истраживачи фолклора и књижевности, Београд: Славистика, 11, 333-344.

Ајдачић 2010: Д. Айдачич, Українські переклади та перекладачі сербської літератури, Київ: Славістичні дослідження: фольклористичні, літературознавчі, мовознавчі, 13-32.

Ајдачић 2015: Д. Ајдачић, (ур.), Српска књижевност у украјинском ЛитАкиенту. 2. доп. изд., Београд: Алма, Кијев: Темпора.

Ајдачић, Татаренко 2016: Д. Айдачич, А. Татаренко, уред. Сербська література XX ст.: хрестоматія, Київ: Освіта України.

Антонова 2017: О. Антонова, Перекладацька рецепція творчості Данила Кіша в Україні, Стиль і переклад, 100-110.

Антонова 2018: О. Антонова, Сучасна сербська проза в Україні: трансфер культур, Одеса: Науковий вісник Міжнародного гуманітарного універcumemy, 34/1, 4-6.

Билик 2003: Н. Білик, Рецепція творчості Іво Андрича в Україні (50-ті - початок 80-х років ХХ ст.), Київ: Мова і культура, 6/ 6/1, 277-285.

Билик 2018: Н. Білик, Стратегї компаративістики в сербському романі порубіжжя $X X-X X I$ сторіч, Київ: Освіта України.

Гогуља 2019: М. Гогуля, Туга за людяністю. Екзистениійний вимір і поетика прози Данила Кіма. Київ: Наукова думка.

Дзјуба-Погребњак 2014: О. Дзюба-Погребняк, Перша світова війна в літеpaтурах південних слов'ян, Київ: Дух і Літера.

Деркач 2013: О. Деркач, Художня картина світу Іво Андрича та ї̈ „жіноча проекція”, Київ: Освіта України.

Лобур, Моторний, Татаренко 2014: Н. Лобур, В. Моторний, А. Татаренко, Мости міжкультурної співпраці: 3 перекладацького досвіду кафедри слов'янської філології Франкового університету, Київ: Компаративні дослідження слов'янських мов і літератур: Пам'яті академіка Леоніда Булаховського, вип. $24,323-331$.

Пашченко 2017: J. Paščenko, Ukrajinska recepcija hrvatske i srpske književnosti tranzicijskog razdoblja, y: V. Karlić, S. Šakić, D. Marinković (ur.), Tranzicija i kulturno pamćenje. Zagreb: Srednja Evropa, 81-92.

Стеблина Рудјакова 2009: Л. Стеблина-Рудякова, Сербістика в Київському університеті імені Тараса Шевченка, <https:/www.rastko.rs/cms/files/ books/4f25dbecf1f15>, 6. 09. 2020.

Татаренко 2001: А. Татаренко, Магично кружење књига: Данило Киш у Украјини, Бања Лука: Крајина, 1, 155-160. 
Татаренко 2002: А. Татаренко, Сусрет култура на граници миленијума или Украјински излет српске књижевности, Панчево: Свеске, 64, 137-142.

Татаренко 2003: А. Татаренко, Рецепція творчості Мілорада Павича в Україні, Львів: Проблеми слов янознавства, 53,113-119.

Татаренко 2006: А. Татаренко, Милорад Павић и његови украјински читаоци, Нови Сад: Летопис Матице српске, 478/4, 690-699.

Татаренко 2010: А. Татаренко, Поетика форми в прозі постмодернізму (досвід сербської літератури), Львів: ПАІС.

Татаренко 2014: А. Татаренко, Венчање речи са телом у пределима (не)могућег: у кругу Павићевог троугла, Нови Сад: Летопис Матиие српске, 494/1-2, 116-146.

Татаренко 2018: A. Tatarenko, Translation as a key and mirror: reception of Serbian literature in today's Ukraine, Poznań: Porównania/Comparations, $1(22), 185-198$.

Шчур 2015: О. Щур, Балканський нерв: книжки про війну в українських перекладах, <http://litakcent.com/2015/07/23/balkanskyj-nerv-knyzhky-provijnu-v-ukrajinskyh-perekladah/> 5. 09. 2020.

Алла Л. Татаренко

УКРАИНСКИЕ МАРШРУТЫ СЕРБСКОЙ ЛИТЕРАТУРЫ: ОСОБЕННОСТИ (ПОСТ)МОДЕРНОЙ РЕЦЕПЦИИ

\section{Резюме}

Данная статья посвящена изучению рецепции сербской литературы в Украине последнего двадцатилетия (1998-2020). Предметом рассмотрения избраны основные векторы академического, переводческого и литературно-критического интереса к произведениям сербских писателей на протяжении двух десятилетий, влияние сербской литературы на творчество современных украинских писателей, реакции украинской литературной критики на опубликованные в Украине переводы с сербского. Обращается внимание на особенности украинской рецепции, продиктованные как культурологическими причинами, так и политическими событиями в этих двух странах. Особое место уделяется постмодерным формам рецепции, прежде всего - связанным с перформативностью, интересом к личности писателя, а также свидетельствам рецепции произведений сербских литераторов в социальных сетях, блогах и других постмодерных медиа. 